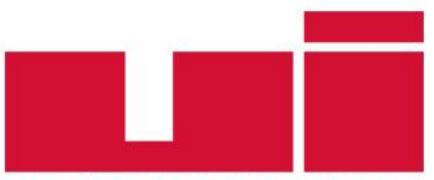

ULLUSLARARASIILIȘKiLER

Akademik Dergi

Yayın ilkeleri, izinler ve abonelik hakkında ayrıntılı bilgi:

E-mail: bilgi@uidergisi.com.tr

Web: www.uidergisi.com.tr

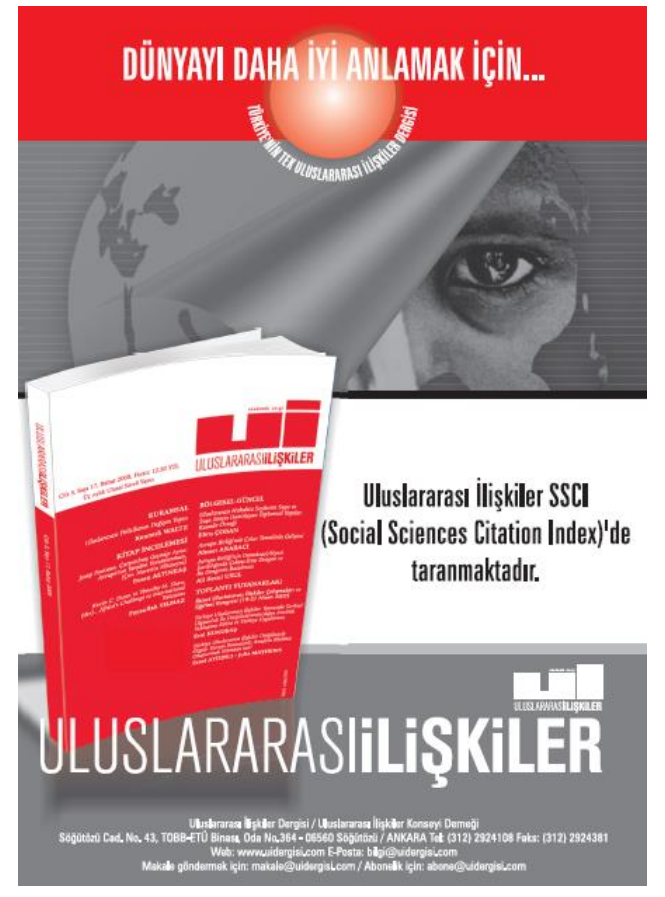

\section{Uluslararası İlişkiler Düşüncesinde "Dünya Barışı": Immanuel Kant ve Zhao Tingyang Felsefesi Üzerine Bir Karşılaştırma}

\section{Filiz ÇOBAN ORAN* ve Cemre PEKCAN**}

* Yrd. Doç. Dr., Uluslararası İlişkiler Bölümü, Çanakkale Onsekiz Mart Üniversitesi

** Yrd. Doç. Dr., Uluslararası İlişkiler Bölümü, Çanakkale Onsekiz Mart Üniversitesi

Bu makaleye atıf için: Çoban Oran, Filiz ve Pekcan, Cemre, "Uluslararası İlişkiler Düşüncesinde "Dünya Barışı": Immanuel Kant ve Zhao Tingyang Felsefesi Üzerine Bir Karşılaştırma“, Uluslararası İlişkiler, Cilt 14, Sayı 55, 2017, s. 3-18.

$\mathrm{Bu}$ makalenin tüm hakları Uluslararası İlişkiler Konseyi Derneği’ne aittir. Önceden yazılı izin alınmadan hiç bir iletişim, kopyalama ya da yayın sistemi kullanılarak yeniden yayımlanamaz, çoğaltılamaz, dağıtılamaz, satılamaz veya herhangi bir şekilde kamunun ücretli/ücretsiz kullanımına sunulamaz. Akademik ve haber amaçlı kısa alıntılar bu kuralın dışındadır.

Aksi belirtilmediği sürece Uluslararası Illişkiler'de yayınlanan yazılarda belirtilen fikirler yalnızca yazarına/yazarlarına aittir. UİK Derneğini, editörleri ve diğer yazarları bağlamaz. 


\title{
Uluslararası İlişkiler Düşüncesinde "Dünya Barışı”: Immanuel Kant ve Zhao Tingyang Felsefesi Üzerine Bir Karşılaştırma
}

\author{
Filiz ÇOBAN ORAN \\ Yrd. Doç. Dr., Uluslararası İlişkiler Bölümü, Biga İİBF, Çanakkale Onsekiz Mart Üniversitesi, Çanakkale. E-posta: \\ filizzcoban@gmail.com \\ Cemre PEKCAN \\ Yrd. Doç. Dr., Uluslararası İlişkiler Bölümü, Biga İİBF, Çanakkale Onsekiz Mart Üniversitesi, Çanakkale. E-posta: \\ cemrepekcan83@hotmail.com
}

\begin{abstract}
ÖZET
$\mathrm{Bu}$ çalışma, Uluslararası İlişkiler düşüncesinde yaygın olarak kabul gören Batı geleneği ve Batı-dışı geleneğin uzlaşmazlığı iddiasına karşı Immanuel Kant' in aydınlanma felsefesinin ve Zhao Tingyang' in çağdaş bir yorum getirdiği kadim Çin'in tianxia felsefesinin "dünya barışı" kavramı üzerine bir karşılaştırma yapmayı amaçlamaktadır. Bu amaçla, öncelikle iki kozmopolitan dünya görüşünün temel kavramlarına açıllık getirilmektedir. Bu kavramlardan hareketle bu iki görüş açısından dünya barışının sürekliliğinin koşulları araştıılmaktadır. Bu normatif karşılaştırma sonucunda Uluslararası İlişkiler literatürüne Çin ve Batı düşüncesini 'dünya barışı' kavramı üzerinde buluşturan ve uzlaştıran özgün bir teorik katkı yapılmaktadır.
\end{abstract}

Anahtar Kelimeler: Batı-dışı Uluslararası İlişkiler Teorileri, Kosmopolitanizm, Tianxia, Barış Çalışmaları, Çin Düşüncesi

\section{"World Peace" in International Relations Thought: A Comparison of Immanuel Kant and Zhao Tingyang Philosophy}

\begin{abstract}
To challenge widely accepted claims regarding irreconcilability of the Western and Non-Western traditions in International Relations thought, this study aims to make a comparison on the concept of 'world peace' inImmanuel Kant's enlightenment philosophy and Zhao Tingyang's modern interpretation of ancient Chine's tianxia philosophy. In accordance with this purpose, first it focuses to shedding a light on the main notions of these two cosmopolitan world views. With a departure from these notions, it searches the main principles of world peace in these two perspectives. As a result of this normative comparison, it makes an original theoretical contributionto International Relations literature which meets and reconciles Chinese thought with Western thought on the concept of 'world peace'.
\end{abstract}

Keywords: Non-western International Relations Theories, Cosmopolitanism, Tianxia, Peace Studies, Chinese Thought 


\section{Giriş}

Uluslararası İlişkilerin bir disiplin olarak ortaya çıkışı ancak Birinci Dünya Savaşı sonrasında Birleşik Krallığın Galler bölgesindeki Wales Üniversitesi’nde Wilson Uluslararası Politika Kürsüsü’nün kurulmasıyla mümkün olmuştur. Bunu, 1923'te Londra'da ve 1930'da Oxford'da kurulan Montague Burton kürsüleri izlemiştir. ${ }^{1}$ İlk uluslararası ilişkiler çalışmalarının odak noktasını uluslararası örgütler, hukuk ve diplomasi gibi devlet idaresiyle ilgili konular oluşturmuştur. Savaştan yorgun düşen devletler, doğal olarak yeni bir savaş çıkmasını engellemek ve sorunların barışçl yollarla çözülmesini sağlamak amacıyla işbirliğine yönelmişlerdir. Birinci Dünya Savaşı ve sonrasında Avrupa merkezli şekillenen dünya tarihinin etkisiyle Uluslararası ilişkiler disiplini Batı merkezli yaklaşımlarla gelişmiştir. ${ }^{2}$

İki büyük dünya savaşının ardından uluslararası sistemde dünya barışını ve güvenliğini sağlamak için oluşturulan Milletler Cemiyeti ve Birleşmiş Milletler gibi örgütlerin ${ }^{3}$ temelinde yatan düşüncenin 18. yüzyıl Aydınlanma dönemi Alman filozoflarından Immanuel Kant'ın "idealizmine" ve "ebedi barış” düşüncesine dayandığı kabul edilmektedir. Kantçı paradigmaya göre devletlerarasında ebedi barış, uluslararası hukuk çatısı altında cumhuriyetçi anayasalarla yönetilen devletlerin uluslararası ticaret ve işbirliği ile birbirine bağlandıkları bir dünya federasyonu ile mümkündür.

Bununla birlikte son dönemde, Uluslararası İlişkiler disiplininde mevcut uluslararası ilişkiler kuramlarının uluslararası barışı değil, Batılı devletlerin çıkarlarını koruduğu ve disiplinin daha farklı seslerle yeniden düzenlenmeye ihtiyacı olduğu öne sürülerek dünya sistemine ilişkin Batılı olmayan yaklaşımlar geliştirme arayışına girilmiştir. Dolayısıyla Batı-dışı ülkelerin ve bölgelerin alana katkıları üzerine çalışmalar yapılmaya başlamıştır. ${ }^{5}$ Güvenilir hiçbir Uluslararası İlişkiler kuramının yalnızca Avrupa'nın tarihsel ve kültürel tecrübesine dayanarak inşa edilemeyeceği iddiasıyla özellikle Çin’in tarihi ve kültürel birikiminin dünya sorunlarını çözmede önemli bir araç olabileceği düşünülmektedir. ${ }^{6}$ Daha da önemlisi, 21. yüzyıldaki jeopolitik gelişmelerle birlikte Çin'in yükselişi ${ }^{7}$ göz önüne alındığında Çin’in uluslararası ilişkilere ve barışa bakışı dikkate alınmaksızın kalııı bir dünya barışının sürdürülebilirliği mümkün görünmemektedir. ${ }^{8}$

1 Nuri Yurdusev, "Uluslararası İlişkiler Öncesi”, Atila Eralp (der.), Devlet, Sistem ve Kimlik: Uluslararası İlişkierde Temel Yaklaşımlar, İletişim Yayınları, 1996, s.26-27.

2 Amitav Acharya ve Barry Buzan, “Why There is No Non-Western International Relations Theory?”, Amitav Acharya ve Barry Buzan (der.), Non-Western International Relations Theory: Perspectives On and Beyond Asia, Routledge, 2010, s.6-7.

3 Mehmet Hasgüler ve M. Bülent Uludağ, Uluslararası Örgütler, Ankara, Nobel Yayınevi, 2005.

4 Immanuel Kant, “Sürekli (Ebedi) Barış Üstüne Felsefi Bir Deneme (1795)”, Seçilmiş Yazılar, İstanbul, Remzi Kitabevi, 1984.

5 AlastairIain Johnston, "What (If Anything) Does East Asia Tell Us About International Relations Theory?", Annual Review of Political Science, Cilt 15, s.53-78; Giorgio Shani, “Towards a Post-Western IR: The Umma, Khalsa Panth, and Critical International Relations Theory”, International Studies Review, Cilt 10, No.4, 2008, s.722-734; Karen Smith, "Has Africa Got Anything to Say? African Contributions to the Theoretical Development of International Relations", The Round Table, Cilt 98, No.402, 2009, s.269-284; Navnita Chadha Behera, "Reimagining IR in India", Acharya ve Buzan (der.), Non-Western International Relations Theory, s.92-117.

6 Nele Noesselt, "Is There a Chinese School of IR?”, GIGA Working Papers, No.188, 2012; Joseph Y.S. Cheng, “Convincing the World of China's Tradition to Pursue Universal Harmony”, Journal of Chinese Political Science, Cilt 17, No. 2, 2012, s.165185;Zhang Yongjin, "China's Entry into International Society: Beyond the Standart of 'Civilisation", Review of International Studies, Cilt 17, No.1, 1991, s.3-16; Tong Shijun, “Chinese Thought and Diological Universalism”, Gerard Delanty (der.), Europe and Asia Beyond East and West, Routledge, 2006, s.305-315; Zhou Lian, "The Most Fashionable and the Most Relevant: A Review of Contemporary Chinese Political Philosophy”, Diogenes, Cilt 56, No.1, 2009, s.128-137.

7 John Ikenberry, “The Rise of China and the Future of the West: Can the Liberal System Survive?”, International Affairs, Cilt 87, No.1, 2008, s.23-37; Robert Ross, "Balance of Power Politics and the Rise of China: Accommodation and Balancing in East Asia”, Security Studies, Cilt 15, No.3, 2006, s.355-395.

8 Örneğin ABD'deki “Çin tehdidi”literatürüne karşı Zhiqun Zhu (2006) 21. Yüzyılda ABD-Çin İlişkileri: Güç Dönüşümü ve Barış adlı kitabında gelecekte $\mathrm{ABD}$ ve Çin arasındaki küresel güç dönüşümünün barışçıl yollarla gerçekleşmesi için yeni bir analitik model önermektedir. 
Buna rağmen, Barış Çalışmaları literatürüne bakıldığında alanın Batı-merkezli geliştiği ve Batı-dışı kavramsallaştırmaları ve yaklaşımları yok saydığı görülmektedir. ${ }^{9} \mathrm{Bu}$ nedenle alan, "barış" kavramının sınırlı bir tanımlamasına hapsolmuştur. Öyle ki, "barış", baskın biçimde "savaşsızlık" durumu olarak kabul görmüş, akademik çalışmalar ağırlıklı olarak "negatif barış" ya da "savaş ve çatışmayı önleme" üzerine odaklanmıştır. ${ }^{10}$ Barış Çalışmalarındaki bu eksikten hareketle, alandaki en yeni çalışmalardan olan The Puzzle of Peace, barışın gelişimini uluslararası sistem düzeyinde anlamak için, barış kavramına savaş ya da çatışmaları temel alan olay-temelli yaklaşımlar yerine, işbirliği gibi pozitif kavramları temel alan ilişki-temelli yaklaşımla daha kapsamlı bir açılkama getirmiştir. ${ }^{11} \mathrm{Bu}$ bağlamda bu çalışma, hem sistem düzeyinde bir araştırma yapması hem de "dünya barışı" kavramı üzerinde Batılı ve Çinli iki yaklaşımın bir arada incelemesiyle Barış Çalışmaları alanına özgün bir katkı yapmayı ummaktadır.

Çin'in dünya politikasına ve barışına yaklaşımını anlamak için, öncelikle Uluslararası İlişkiler disiplininin Çin'de nasıl geliştiğine açıklık getirmek gerekmektedir. Çin'de Uluslararası İlişkiler disiplinin kuruluşu, Çin Halk Cumhuriyeti'nin ilk başbakanı Zhou Enlai'nin 1949'da yaptığı bir çağrıyla başlamıştır. ${ }^{12}$ Ancak, Çin'in dış dünyaya açılmasına kadarki süre içerisinde, tüm sosyal bilimler alanlarında Maoist politikalar, Marksist-Leninist ideoloji ve Sovyetler Birliği etkili olmuştur. ${ }^{13}$ Bu yüzden Çin'in ilk otuz yılında uluslararası ilişkiler çalışmaları daha çok Parti'ye hizmet etmiştir. 1980'de kurulan "Uluslararası İlişkiler Tarihi Ulusal Derneği”, bu alanda kurulmuş ilk ulusal çaplı akademik kuruluştur. ${ }^{14} 1987$ 'de Şangay'da düzenlenen Çin’in ilk büyük Uluslararası İlişkiler Kuramı Konferansı'nda, Çin'in kendi teorilerini üretmesi gerektiği dile getirilmiştir. ${ }^{15}$ Tiananmen Meydanı Olayları Çin'in diğer ülkelerle ilişkilerini sekteye uğrattığı gibi, uluslararası ilişkiler çalışmalarını da yavaşlatmıştır. 1992'den itibaren durum düzelmeye başlamış, dünyada barış ve gelişme, çok kutupluluk, ekonomik küreselleşme, stratejik ortaklık, uluslararası güvenlik gibi yeni konular Uluslararası İlişkiler alanının çalışma konuları olmuştur. ${ }^{16}$

Çin dış politikasındaki en etkili isimlerden biri olan Qin Yaqing de Çin'in tüm uluslararası ilişkiler çalışmalarına yeniden yön verebilecek entelektüel geleneğe sahip olduğunu ileri sürmüştür. ${ }^{17}$ Bu bağlamda Çin, son dönemde uluslararası ilişkiler teorilerine ve uluslararası barış ve uyuma katkı yapmak için çalışmalarına devam etmektedir. Çin'de Uluslararası İlişkiler Teorilerinin gelişimine,

9 Bkz.David P. Barash, Approaches to Peace: A Reader in Peace Studies, NY, Oxford University Press, 2013; Charles Webel ve Johan Galtung (der.), Handbook of Peace and Conflict Studies, NY, Routledge, 2009.

10 Nils Petter Gleditsch, Jonas Nordkavelle ve Håvard Strand, "Peace Research-Just the Study of War?" Journal of Peace Research, No.51, Mart 2014, s.145-158.

11 Gary Goertz, Paul F. Diehl veAlexandru Balas, The Puzzle of Peace: The Evolution of Peace in the International System, NY, Oxford University Press, 2016.

12 Gustaaf Geeraerts ve Men Jing, "International Relations Theory in China”, Global Society, Cilt 15, No.3, 2001 , s.253.

13 David Shambaugh, "International Relations Studies in China: History, Trends and Prospects", International Relations of the Asia-Pacific, Cilt 11, No.3, 2011, s.340.

141999 yılında ismi "Uluslararası Çalışmalar Çin Ulusal Derneği” (China National Association for International StudiesCNAIS) olarak değişmiştir.

15 Zheng Feng, "Debating the Chinese Theory of International Relations", Fred Dallmayr ve Zhao Tingyang (der.), Contemporary Chinese Political Thought: Debates and Perspectives, The University Press of Kentucy, 2012, s.70.

16 Shambaugh, "International Relations Studies in China", s.340.

17 Allen Carlson, "Moving Beyond Sovereignty? A Brief Consideration of Recent Changes in China's Approach to International Order and the Emergence of the Tianxia Concept", Journal of Contemporary China, Cilt 20, No.68, 2011, s.98. 
bu çalışma içerisinde yer verilecek olan Zhao Tingyang'in yanı sıra, Qin Yaqing, ${ }^{18}$ Yan Xuetong ${ }^{19}$ ve Zheng Bijian ${ }^{20}$ gibi isimler de önemli katkılar yapmışlardır. Çin Komünist Partisi Ekolü’nün eski başkan yardımcısı Zheng Bijian, 2003 yılında yaptığı bir konuşmada "barışçıl yükseliş" kavramını ortaya atmış, sosyalizmin Çin değerleriyle inşa edilerek, küresel ekonomiye katılım sağlandığı takdirde, hegemonya amacı güdülmeden dünya barışına katkıda bulunabileceğini ifade etmiştir. ${ }^{21}$

Çin’ in uluslararası barış ve uyuma katkılarına ilişkin çalışmalar artmasına rağmen Batı-merkezli kültürel görecelilik perspektifi, Kant'ın ebedi barış projesinin ancak Batılı devletler arasında ya da “Avrupalılaşmış kültürlerle” gerçekleşebileceğini iddia etmektedir. "Medeniyetler Çatışması mı?” adlı çalışmasıyla çok ses getiren S. P. Huntington demokrasinin Batı-dışı toplumlara yayılamayacağını, yayılmasının sadece tepki doğuracağına inanmaktadır. ${ }^{22} \mathrm{Bu}$ görüşe göre, demokratik barış sadece Avrupalı devletlerarasında kurulabilecektir. "Çin tehdidi hipotezinin" oluşmasında önemli katkısı olan Richard Bernstein ve Ross Munro demokrasinin saldırgan ve yayılmacı Çin siyasal kültürüne bir tezat oluşturduğunu öne sürmüşlerdir. ${ }^{23} \mathrm{Bu}$ kültürcü yaklaşımlar, Asya değerlerinin Batı kaynaklı siyasi ve felsefi idealler üzerine geliştirilen evrensel insan hakları görüşüyle uyumu üzerine tartışmaları da tetiklemiştir. ${ }^{24}$

Batılı ve Batı-dışı yaklaşımların dünya siyasetine ve uluslararası ilişkilere bakışlarının farklı olduğu varsayımını sorgulayan, dikkate değer çalışmalardan biri Pınar Bilgin'in Thinking Past 'Western' IR? Başlıklı makalesidir. ${ }^{25}$ Literatürde yaygın biçimde kabul gören bu farklılık varsayımına karşı Bilgin, Batılı ve Batı-dışı dünyayı yorumlama biçimlerinin ve deneyimlerinin birbirleriyle karşılaşmaları, mücadeleleri ve iç içe geçişleriyle benzer kavramlar ve bakış açıları geliştirebileceklerini iddia etmektedir. Bu iddiasını, Hindistan’n nükleer statü arayışı, Türkiye'nin sekülerliğe geçişi ve Asya’nın liberal dünya düzeniyle entegrasyonu olmak üzere Batılı olmayan üç örneğe odaklanarak doğrulamaktadır.

Benzer bir yaklaşımla Manik V. Suri, Kantçı ebedi barış paradigmasının Çin siyaset felsefesiyle uzlaşmazlığını iddia eden yaygın hipotezlerin temelde eksik ve yetersiz dayanakları olduğuna karşı çıkarak, Kant felsefesinin ve liberal uluslararasıcılık yaklaşımının klasik Çin siyaset felsefesindeki ve çağdaş Çin diş politika söylemindekiizdüşümlerini ortaya koymuştur. ${ }^{26}$ Kökleriklasik Konfüçyüsçülüğe

18 Qin Yaqing, "Why There is no Chinese International Relations Theory", International Relations of the Asia Pacific, Cilt 7, 2007, s.316.

19 Yan Xuetong, Ancient Chinese Thought, Modern Chinese Power, Daniel A. Bell ve Sun Zhe (der.), Princeton University Press, 2011.

20 Liu Guoli, “Domestic Sources of China's Emerging Grand Strategy", Journal of Asian and African Studies, Cilt 43, No.5, 2008, s.544.

21 Diğer Çinli Uluslararası İlişkiler uzmanlarının Asya'daki güç dönüşümü üzerine görüşleri için ayrıca bkz. Hung-Yen Wang, "How Chinese International Scholars Addressing Asia's Current Power Transition”, David Walton ve Emilian Kavalski (der.), Power Transition in Asia (Rethinking Asia and International Relations), NY, Roudledge, 2016, s.59-75.

22 Samuel P. Huntington, The Clash of Civilizations and the Remaking of World Order, NY, Simon\&Schuster, 2011.

23 Richard Bernstein and Ross Munro, The Coming Conflict with China, NY, Vintage Books,1997.

24 Karen Engle, "Culture And Human Rights: The Asian Values Debate In Context”, 32 N.Y.U. J. International Lawe Politics, No.291, 2000; Michael C. Davis, "Constitutionalism and Political Culture: The Debate over Human Rights and Asian Values”, 11 Harvard Human Rights Journal, No.109, 1998.

25 Bkz. Pınar Bilgin, “Thinking Past ‘Western' IR?”, Third World Quarterly, Cilt 29, No.1, 2008, s. 5-23. Pınar Bilgin, başka bir çalışmasında Batı́nın deneyimlerini evrensel kabul eden ve Batı-dışı güvenlik ve güvensizlik yaklaşımlarını tarihsel olarak yok farz eden Güvenlik Çalışmalarının Batı-merkezli gelişimini eleştirmektedir. Bkz. “The ‘Western-Centrism’ of Security Studies: Blind Spot or Constitutive Practice?”, Security Dialogue, No.41, 2010, s.615.

26 Manik V. Suri, “Conceptualizing China Within the Kantian Peace”, Harvard International Law Journal, Cilt 54, No.1, 2013, s.219-232. 
kadar götürülebilen Çin’in saklı liberal mirasının yeniden inşasının yeni dünya düzeninde barışın tesisi için daha iyi bir şans doğuracağı savından hareketle, öncelikle Kantçı ve Konfüçyüsçü paradigmaları ${ }^{27}$ test eden Suri, her iki dünya görüşünün paylaştığı ortak liberal varsayımları incelemiş, Çin ve Batı düşüncesinin uzlaşmazlığı hipotezini çürütmüştür. Bu ve benzeri akademik çabalar, Batı'nın Çin’i sürekli bir tehdit olarak görüp güvenlikleştirici politikalara itip çatışma zemini hazırlayan "güvenlik ikilemi” yaratması yerine Kantçı liberalizm ve reformist Konfüçyüsçülükle tanımlanan pasifist ve savunmacı Çin kimliğini teşvik etmeye çağırmaktadır. ${ }^{28}$

$\mathrm{Bu}$ çalışma da çıkış noktası olarak Batı-merkezli yaklaşımların Batı-dışı siyasi geleneklere kültürcü ve indirgemeci bakış açılarının kritiğini alarak, çoklu modernite ve demokrasi deneyimleri ${ }^{29}$ ve farklı barış geleneklerinin varlığının ön kabulüyle Kant'ın ebedi barış görüşüyle Çin felsefesinin kozmolojik dünya görüşü tianxianın yaklaşımlarını karşılaştırmaktadır. ${ }^{30}$ Bunun için, Çin ve Kant felsefesi ilişkisi üzerine yapılan diğer çalışmalardan farklı olarak, ${ }^{31}$ spesifik olarak "dünya barışı" kavramına odaklanılmakta, ayrıca tianxia'ya modern bir bakış açısı getiren Çinli Profesör Zhao Tingyang' in ${ }^{32}$ görüssleri temel alınmaktadır. ${ }^{33}$

Zhao’a göre, Batı́nın Çin'i bir tehdit olarak görmesinin başlıca nedenlerinden biri, Batı dünyasının Çin’in dünya görüşünü anlamamasıdır. Zhao, uluslararası ilişkileri tanımlayan Batılı üç kültür biçimine ${ }^{34}$ ek olarak, dördüncü bir kültür olarak Batılı olmayan tianxia kültürünü önermektedir. ${ }^{35}$ Çünkü ne dünyanın düşmanlarla çevrili olduğu varsayıma dayanan Hobbesçu kültür ne de rekabetin savaşın yerini aldığı bir sistem öngören Lockçu kültür dünyadaki çatışmaların son bulmasına hizmet etmektedir. Dost devletlerle bir dünya federasyonunu savunan Kantçı kültür, barış için diğer iki kültürden daha güçlü olsa da tianxia, düşmanı dosta dönüştürebilmesiyle dünya barışı için daha etkili bir ilişki biçimi sunmaktadır. ${ }^{36}$

27 Konfüçyüs düşüncesi için, Dört Kitap'ın yanı sıra (Analects, Mencius, Daxue ve Zhongy-ong), ayrıca Xunzi ve Yizhuan öğretilerine başvurmuştur.

28 Victoria Tin-bor Hui, “Toward a Confucian Multicultural Approach to a Liberal World Order: Insights from Historical East Asia”, American Society of International Law, Cilt 99, 2005, s.413-416; Edward Friedman, "Immanuel Kant's Relevance to an Enduring Asia-Pacific Peace”, Edward Friedman ve Barrett L. McCormick (der.), What if China Doesn't Democratize? Implications for War and Peace, NY, M. E. Sharpe, 2000, s.224- 252.

29 "Çoklu demokrasiler" kavramı, her toplumda modernitenin gelişiminin farklı tarihi ve sosyal bağlamlarda oluşması gibi demokrasinin de sadece prosedürel bir kurumsallaşmadan ibaret olmadığını savunur. Tekçi ve minimalist bir demokrasi tanımı yerine, "çoklu demokrasiler" ile farklı medeniyetlerde toplumun farklı kesimlerince demokrasinin evrensel normlarının farklı yorumlamaları sonucu çeşitli kültürel ve yerel özgürleşme mücadelelerinin farklı siyasi geleneklerle ilişkisinde şekillenen çoklu deneyimlerine dayanan değişken tanımlamaları araştırılır. Bkz.S. N. Eisenstadt, "Multiple Modernities", Daedalus, Cilt 129, No.1, 2000, s.1-29.

30 Tianxia; Çince'de, gökyüzü, gökler, en yukarıda anlamında olan tian (天) ve aşağıdaki, alttaki anlamındaki xia (下) karakterlerin birleşmesinden oluşan bir sözcüktür. Böylelikle, tianxia "gögün altındaki her şey" olarak Türkçe’ye çevrilebilir.

31 Julia Ching, "Chinese Ethics and Kant", Philosophy East and West, Cilt 28, No.2, 1978, 161-172.

32 Zhao Tingyang, "All-Under-Heaven and Methodological Relationism: An Old Story and New World Peace”, Fred Dallmayr veZhao Tingyang (der.), Contemporary Chinese Political Thought: Debates and Perspectives, The University Press of Kentucy, 2012, s.46-66; Zhao Tingyang, "A Political World Philosophy in terms of All-Under-Heaven (Tianxia), Diogenes, Cilt 56, No.5, 2009, s.5-18.

33 Çin felsefesinde dünya barışı ve uyumunu öngören bu yaklaşımın Çin'in dış ilişkilerini ve bunun altında yatan geleneği şekillendirdiği iddia edilmektedir. Bkz. William A. Callahan, “Tianxia, Empire and the World: Soft Power and China’s Foreign Policy Discourse in the 21st Century”, BICC Working Paper Series, British Inter-University China Centre, No.1, 2007, s.6.

34 Bu sinıflandırma için bkz. Alexander Wendt, Social Theory of International Politics, Cambridge University Press, 1999.

35 Zhao Tingyang, "Chinese World Outlook: All-under-Heaven System” Zhenglai Deng (der.) Globalization and Localization: The Chinese Perspective, World Scientific Publishing Company, 2011, s.151.

36 Ibid., s.152. 
Zhao'nun da ortaya koyduğu gibi tianxia' yla karşılaştırmaya en uygun Batılı yaklaşım Kant'ın ebedi barış görüşüdür..$^{37} \mathrm{Bu}$ nedenle bu makale, insanlığın barış ve uyumu için evrensel dünya kurumu öneren bu iki kozmopolitan felsefenin dünya barışı ve uluslararası işbirliğine yaklaşımlarını bir arada ele alarak Barış Çalışmalarına da bir katkı sağlamaktadır. Uluslararası ilişkilerde ulus-devleti temel analiz düzeyi alan teorilerin ve savaşsızlık kavramından türeyen olay-temelli barış yaklaşımlarının ötesine geçerek, Batılı ve Batı-dışı yaklaşımları harmanlayan ilişki-temelli bir yaklaşımla "dünya barışına” daha kapsamlı bir açıklama getirilebileceğini göstermektedir. Ayrıca, Kant ve Çin idealizminin kavramlarının birbirinden beslenme ve simbiyotik gelişmesiyle uluslararası ilişkilerde "güvenlik" ve "tehdit" kavramlarının yerine "işbirliği” ve "uyumun” öne çıkmasına zemin hazırlayabileceği düşünülmektedir.

Bu bağlamda bu çalışma üç bölümden oluşmaktadır. İlk bölümde, Immanuel Kant'ın “insan” ve siyaset görüşüyle Ebedi Barış Üstüne Denemesinde öne çıkan argümanları ele alınmaktadır. İkinci bölümde, çağdaş Çin felsefecisi Zhao Tingyang'in tianxia yaklaşımının kökenleri açıklanırken, son bölümde bu iki kozmopolitan dünya görüşünün dünya barışı üzerine önerileri karşılaştırılarak değerlendirilmeler yapılmaktadır.

\section{Immanuel Kant Felsefesinde Ebedi Barış'ın Temel İlkeleri}

Kant, Ebedi Barış Üstüne Felsefi Deneme’sini 5 Mayıs 1795'te Basel'de imzalanan Fransa-Prusya Barış Antlaşmasının ardından yazmıştır. Bu Antlaşma, Fransız Devrimi’nin eşitlik, özgürlük ve kardeşlik idelerinin halk iradesiyle anayasal vatandaşlık altında koruma altına alınmasının idealize edildiği siyasi atmosferde, Kant'ın devletlerarasında barışın sürekliliği için devletlerarası hukuku ve cumhuriyet yönetimini şart görmesinde etkili olmuştur. Ayrıca, Kant'in ebedi barış görüşü Aydınlanma manifestosunun devamı olarak değerlendirilebilir. Nitekim Kant, 1784’te kaleme aldığ Aydınlanma Nedir Sorusuna Yanıt'ta, "Aydınlanmayı" insanların kendi suçu ile düşmüş olduğu ergin olmama durumundan kurtulması olarak tanımlamaktadır. ${ }^{38} \mathrm{Bu}$ ergin olmayış durumunun nedeni, insanın kendi aklını, bir başka aracı ya da kılavuza başvurmaksızın kullanamayışıdır. Kişilerin kendi kaderleri konusunda kararları başkalarına bırakmasıdır. Oysa Aydınlanma için cesaret ve özgürlük gerekmektedir. Devlet, iyi yasaların yapılması ve yönetilmesi için vatandaşların özgürce akıllarını kullanabilmelerinin önünü açıp düşüncelerini almalı, insanın insansal onuruna uygun muamele gördügü bir sistemi garanti altına almalıdır. ${ }^{39}$ Böylelikle Kant, devleti soyut bir kurum, salt bir toprak parçası ya da taşınmaz mülkiyete indirgememektedir. Devlet, kendi hakkında ancak kendisinin karar verebileceği ve kimsenin buyruğuna ve arzusuna bağlı olmayan bir insan topluluğudur. ${ }^{40}$

Kant'ın insan ve siyaset felsefesi, kendinden önceki üç yüzyıla damgasını vuran matematik ve fiziğin başarılarından oldukça etkilenmiştir. Kant, insan aklında, matematik ilkeleri gibi genel-geçer, evrensel ve kesin ilkeler aramıştır. Ona göre hem yasa koyucu hem de yasaya bağlı olan insanlar sistematik bir birlikle amaçlar krallığını oluşturmaktadırlar. ${ }^{41}$ Kant, kaynağı akılda bulunan bir kesin "buyruk" ${ }^{42}$ ve temel ahlaki ödevi saptamıştır. Bu buyruğa göre, akıl sahibi varlık olan insan, kendisine

37 Kant'ın Çin ve Çin felsefesi üzerine bir değerlendirme için bkz. Gregory M. Reihman, “Categorically Denied: Kant's Criticism of Chinese Philosophy", J. Chinese Phil. No.33, 2006, s.51-65.

38 Immanuel Kant, “Aydınlanma Nedir Sorusuna Yanıt (1784)”, Immanuel Kant, Seçilmiş Yazılar, İstanbul, Remzi Kitabevi, 1984, s.213-215.

39 Ibid., s.221.

40 Kant, "Sürekli (Ebedi) Barış", s.227.

41 Immanuel Kant, Ahlak Metafiziğinin Temellendirilmesi, Ankara, Türkiye Felsefe Kurumu, 2002, s.51.

42 Ibid., s.29. 
ve diğer insanlara hiçbir koşulda sadece araç olarak davranmamalı, amaç olarak görüp eylemelidir. Eylemlerinin altında yatan istemenin ahlaksal olarak iyi olması, eylemin ilkesinin herkes için genel bir yasa olmasını isteyebilmekte yatmaktadır. ${ }^{43}$

Herkesin diğer insanların haklarını koruduğu bu amaçlar krallığında, sürekli barış, insanlık için sadece siyasi değil aynı zamanda ahlaki bir amaçtır. Bunun önündeki en büyük engel bireysel egoizmdir. İnsan, akıl ve ahlaki olgunlukla doğasındaki bencilliğe karşı çoğulcu ve kozmopolitan düşünce yapısıyla bu engeli aşabilir. Kant, herkesin herkese karşı çıkar karşıtlığı nedeniyle savaş halinde olduğu, güce dayalı, adaletsiz bir dünyanın bencil bireyleri olmaktansa kendini insanlığın bir üyesi ve "safi dünya vatandaşı" olarak görmenin olanağına işaret ederek, insan hakları ve dünya barışının felsefi temellerini atmıştır. ${ }^{44}$ Bilim ve güzel sanatlar karşılıklı anlayış ve iletişim kültürünü geliştirerek bu ortak ilkeler üzerinde anlaşmayı sağlayıp insanların medeni bir topluma ve ahlaki olgunluğa erişmesine katkıda bulunmaktadır. Sadece kendi çıkarını gözeten hırslıların tiranlığına karşı bilim ve sanat bireylerin kendilerini kozmopolitan anlamda dünya toplumunun bir parçası olarak görmelerini sağlayarak kültürel ve ahlaki ilerlemeyi olanaklı kılmaktadır.

Immanuel Kant için barış hem fiili hem de düşünce ve yaklaşım olarak tüm düşmanlıkların sona ermesidir. Savaş kaçınılmaz ve engellenemez bir durum değildir; üzerinde karar verilen iradi bir girişimdir. Kant'ın Ebedi Barış Üstüne Felsefi Deneme’sinde tanımladığı devletlerarasında barışı sağlamayı öngören üç amaçsal (nihai) maddesi şunlardır: ${ }^{45}$

1- Her devletin sivil anayasası cumhuriyetçi olmalıdır.

2- Devletler hukuku, bağımsız devletlerden kurulu bir federasyona dayanmalıdır.

3- Dünya vatandaşlığı hukuku, evrensel konukluk koşulları ile sınırlandırılmalıdır.

Yukarıda sıralanan Kant'ın sürekli barış için amaçsal maddeleri, tüm devletlerin cumhuriyet rejimi ile yönetilip dünya vatandaşlık hukukunun bu devletlerin oluşturduğu federasyonca korunduğu bir uluslararası sistemi öngörmektedir. Vatandaşların kendi kendini yönettiği ve bağımsız yargıyla haklarının korunduğu temsili anayasal sistemler siyasal despotizme karşı liberal sivil toplumu güçlendirmektedirler. Kant’a göre bunun için düşünce, ifade ve iletişim özgürlüğünün korunması şarttır. ${ }^{46}$ Benzer şekilde egemen halkların oluşturduğu hukuka dayalı uluslararası sistemde bir devletin diğer devletler üzerinde gücünü kötüye kullanmasının önüne küresel siyasi yapılanmalar geçebilecektir. Tüm halkların kendi iradeleriyle dünya vatandaşları olarak oluşturdukları dünya federasyonu barışı sağlayabilecektir. ${ }^{47} \mathrm{Bu}$ görüş uluslararası düzende barış ve güvenliğin sağlanması için devletlerin uluslararası örgütler çatısı altında birleşip birbirlerinin güç kullanımını sınırlandırdıkları oluşumlara ilham vermiş, uluslararası hukuk ve etiğe düşünsel kaynak oluşturmuştur.

Kant’a göre ister küçük ister büyük olsun hiçbir bağımsız devlet hiçbir şekilde başka herhangi bir devletin egemenliği altına girmemelidir. ${ }^{48}$ Egemenlik biçimlerine göre devletler otokrasi, aristokrasi ve demokrasi olmak üzere üçe ayrılmaktadır. Yönetim biçimlerine göre ise devletler temel

43 Ibid. s. 15.

44 Marc Lucht, “Toward Lasting Peace: Kant on Law, Public Reason, and Culture”, American Journal of Economics and Sociology, Cilt 68, No.1, 2009, s.312.

45 Kant, Seçilmiş Yazılar, s.225-266.

46 Ibid., s.319.

47 Pauline Kleingeld, “Approaching Perpetual Peace: Kant's Defence of a League of States and his Ideal of a World Federation”, European Journal of Philosophy, Cilt 12, No.3, 2004, s.304-325.

48 “Devletlerarasında sürekli barışın ön maddeleri: Madde II.” Kant, “Sürekli (Ebedi) Barış”, s.227-228. 
olarak cumhuriyetçi ya da despotiktirler. İdeal yönetim biçimi demokrasi olsa da devletlerin sürekli barışı sağlamak adına demokrasi ile yönetilmeyen rejimlere Batılı anayasal standartları güç kullanarak dayatması doğru değildir. ${ }^{49} \mathrm{Bu}$ tür bir müdahale, devletlerin başka devletlerin içişlerine karışmaması ilkesine aykırı olacaktır. Halklar insan haklarını sürekli olarak ihlal eden despotik rejimlere karşı başkaldırmalıdırlar. Kant’a göre, cumhuriyetle yönetilen devletlerde iktidardaki karar vericilerin halkın egemenliğini temsil edip koruması için anayasal yükümlülüklerle hesap vermesi, gücün kötüye kullanımını engellemektedir. Demokratik ülkelerde olduğu gibi insanlık da despotizmin tehlikelerine karşı işbirlikçi ve barışçı dünya düzeni kurmakiçin karşılıklıgörevve sorumluluklar altında birleşmelidir. Tersi bir durum, devletlerin sürekli barışı sağlamak uğruna sürekli savaşta olmasına neden olacaktır. ${ }^{50}$

Çin bakış açısına göre Batı'daki hegemonya yarışı ve güç mücadeleleri nedeniyle Kant'ın barış ideali gerçekleşememiştir. Çinli akademisyenlere göre, Batı́nın bilim, teknoloji ve ekonomideki üstünlüğü Batılı güçlerin küresel baskıyı sürdürmelerine hizmet edip dünya toplumunun kültürel farklılıklarıyla hep birlikte yaşama, gelişme ve kalkınmasına engel olmaktadır. ${ }^{51} \mathrm{Bu}$ anlayış açısından uluslararası örgütler de Batılı devletlerin bu amaçla şiddet ve güç kullanma eylemlerini meşru göstermelerine hizmet etmektedir.

Dünya barışı için demokratik devletlerin uluslar üstü yapılarla ve karşılıklı ekonomik bağımlılık ilişkileriyle birbirine bağlandığı bir dünya federasyonu öngören Kant kozmopolitanizmine karşı Çin kozmopolitanizmini anlamak için makalenin bir sonraki bölümü tianxia felsefesine açılık getirmektedir.

\section{Zhao Tingyang Felsefesinde Tianxia'nın Temelleri}

Çin'de, Qin Hanedanlığı́nın M.Ö. 221'de ülkeyi tek çatı altına toplamasından önceki yaklaşık 3000 yıllık dönem, "üç hanedanlığın altın çağı” olarak anılmaktadır. Bu altın çağda özellikle Zhou hanedanlığı 400 yıl boyunca devam eden bir barış sürecini yaşamışır ve bu bakımdan tianxia imparatorluğuna en güzel örnek olarak gösterilmektedir. Zhou Hanedanlığı’nın ilk liderlerinden Zhou-Gong, birçok kabileyi yönetebilmek ve taleplerini karşılayabilmek amacıyla tüm kültürlerin birbiriyle uyum içerisinde yaşayabileceği, tüm dünyanın kamu yararını en üst düzeyde gözeten evrensel bir dünya sistemi düşüncesi öne sürmüştür. ${ }^{52}$ Zhou döneminde ortaya atılan tianxia düşüncesi Qin-Han imparatorluklarının varlıklarını ve davranışlarına yön veren üstün bir ahlaki otorite fikrini tanımlamak amacıyla da kullanılmıştır. ${ }^{53}$ Qin İmparatoru ilk kez tüm toprakları birleştirip imparatorluğu oluşturduğunda bunu "tüm dünya" anlamına gelen tianxia yitong (天下一统) olarak isimlendirmiş ve bu durum Qin devletini uzun yıllardır savaştığı diğer altı devletin üstüne çıkarmıştır. Qin Hanedanlığı'ndan sonra gelen Han devleti de kökenleri Çince'de imparatorluk anlamına gelen “di-guo" (帝国) kelimesi ile eş anlama gelen ve modern dünya devleti olarak çevrilen yeni bir tianxia yaratmıştır. ${ }^{54} \mathrm{Bu}$ tanımda imparator dünyadaki bir devletin değil, tüm dünyanın yasal yöneticisidir. Buradaki temel nokta Çin düşüncesinde en büyük siyasal oluşumun tianxia, yani herhangi bir devletten

49 “Devletlerarasında sürekli barışın ön maddeleri: Madde V." Kant, “Sürekli (Ebedi) Barış”, s.229-230.

50 Luigi Caranti, "Perpetual War for Perpetual Peace? Reflections on the Realist Critique of Kant's Project”, Journal of Human Rights, Cilt 5, No.3, 2006, s.341-353.

51 Cheng, “Convincing the World”, s.168.

52 Tingyang, "All-Under-Heaven and Methodological Relationism”, s.56.

53 Ibid., s.132-133.

54 Wang Gungwu, Renewal: The Chinese State and the New Global History, The Chinese University Press, 2013, s.15. 
çok daha üst seviyede yer alan bir dünya imparatorluğu olmasıdır. ${ }^{55}$ Tianxia sistemi, 19. yüzyılın ortalarında Avrupa'da Vestfalya sisteminin yayılmasıyla birlikte sona yaklaşmış, Çin'de son hanedanlık olan Qing Hanedanlığı'na karşı devrimin başlatıldığı ve imparatorluğun yıkılıp Çin Cumhuriyeti’nin ilan edildiği 1911 yılında son bulmuştur. ${ }^{56}$

Çin'in üç bin yıllık geleneksel bir kavramı olan tianxia, cennetin oğlu tarafindan yönetilen göklerin altındaki kutsanmış tüm medeni dünyayı kapsamaktadır. Çinliler, "ulus” kelimesinden tüm insanlığı, "devlet" kelimesinden de dünyayı ya da tianxia'yı anlamaktaydılar. Bu anlayışa göre tianxia Çin'i merkeze alan, doğuda Kore Yarımadası'ndan batıda Arabistan ve Pers ülkesine uzanan, keşfedilmiş kültürel dünyayı oluşturuyordu. ${ }^{57} \mathrm{Bu}$ tianxia sistemi hükümdarlarının en büyük ve nihai hedefi tüm ulusların ve tüm insanların uyum içerisinde yaşamasını sağlayan bir dünya politikası oluşturmaktı. ${ }^{58}$

Tianxia, her ne kadar Çin’i dünyanın merkezinde gören bir sistemmiş gibi algılansa da Profesör Zhao Tingyang, bu algıyı kırabilmek ve uluslararası ilişkiler çalışmalarına Çin bakış açısıyla bir katkı sağlayabilmek adına Çin'in köklü ve geleneksel kavramı olan tianxia'yı günümüz dünyasına uyarlayan bir kitap yazmıştır. Zhao, 2005 yılında basılan Tianxia Sistemi: Bir Dünya Kurumu Felsefesine Giriş adlı kitapta, tianxia kavramının dünya barışına ne şekilde katkı sağlayabileceğine dair değerlendirmelerde bulunmuştur. ${ }^{59}$

Klasik Çin yazılarında, dünya ya da Çin anlamında kullanılan tianxia'nın Zhao Tingyang’a göre iç içe geçmiş üç anlamı vardır. Bunlar birbiriyle bağlantılıdır ve birbirlerinden ayrıldıkları takdirde tianxia yok olur: yerküre, insanlar ve dünya kurumu. ${ }^{60}$ Tianxia'nın ilk anlamı tüm topraklar ya da cennetin altındaki her şey anlamına gelen "yerküre"dir (Di, 地). ${ }^{61}$ Yerküre, Çin'de her şeyi içine alan bir ev gibi düşünülerek sadece mekânsal değil, insanların duygularıyla ve yaşamla yakından ilişkilendirilmiş kapsamlı bir anlam taşımaktadır. Tianxia'nın ikinci anlamı “insanlar” (人- rén) veya “tüm insanların kalpleri”dir (民心- mín xin). Çin anlayışına göre dünya insanlar için bir evdir ve İmparator "yerküre"de yaşayan tüm insanların desteğini almadığı sürece orayı yönetiyor sayılamaz. Tianxia yönetimi zora ve baskıya değil, insanların desteğini alıp iyi bir yönetimle onları memnun etmeye dayanmaktadır. Çünkü klasik Çin anlayışına göre tianxia, tek bir ailedir. Dolayısıyla, tianxia'nın bir diğer anlamı insanların tek bir aile olarak algılandığı evrensel bir sistem, yani "dünya kurumu"dur (世界制度-shì jiè zhì dù). Dünya kurumu felsefesi geleneksel Batı imparatorluklarından farklıdır. $\mathrm{Bu}$ imparatorlukta kurumsallaşmış bir dünya toplumu anlayışı yer almaktadır. ${ }^{62} \mathrm{Bu}$ açıklamalardan anlaşılacağı gibi, kavramın bu üç anlamı birbirinden ayrı düşünülememektedir. Tianxia İmparatorluğu yalnızca bir toprak parçası değil, tüm insanlar ailesinden oluşan bir dünya kurumudur.

Özetle, tianxia kavramı, tüm dünya, tüm insanlık ve dünya kurumu olmak üzere coğrafi, psikolojik ve siyasi anlamlarıyla bir üçlü birliği ifade etmektedir.

55 Zhao Tingyang, “The Concept of All-under-heaven: A Semantic and Historical Introduction”, s.2, http://www.doc88. com/p-998593945884.html (Erişim Tarihi 27 Ekim 2016).

56 Fei-Ling Wang, "Between Tianxia and Westphalia: Chinese Searches its Position in the World", Paper Presented at the Annual Meeting of the American Political Science Association, Seatle, 2011, s.13.

57 Cheng, "Convincing the World", s.170.

58 Tingyang, "All Under Heaven”, s.46.

59 Zhao Tingyang, The Tianxia System: An Introduction to the Philosophy of a World Institution, China Renmin University Press, 2011.

60 Callahan, “Tianxia, Empire and the World”, s.6.

61 Zhao Tingyang, “Rethinking Empire From a Chinese Concept 'All-Under Heaven' (Tian-xia, 天下)”, Social Identities, Cilt 12, No.1, 2006, s.30.

62 Tingyang, “The Concept ofAll-under-heaven”, s.6. 


\section{Kant ve Zhao Felsefesinde “Devlet" ve "Yönetim” Anlayışı}

Batılı sistemlerde en temel siyasi birim ulus-devlet kabul edilmekteyken, bu hiyerarşiyi topluluklar ve bireyler izlemektedir. Kant' 'n felsefesi de ulus-devlet fikrini desteklemektedir. Ancak Çin anlayışına göre en üst siyasi oluşum, uluslararası toplum diyebileceğimiz tianxia'dır; devletlerse bunun alt birimleridir. Zhao'ya göre ulus-devlet en üst birim olduğu sürece onun çıkarları her zaman daha önce gelir. Yine Zhao'ya göre küreselleşme bizi, uluslararası çatışmaları azaltmak ve evrensel refahı sağlamak yerine, ulusdevletlerin çıkarlarını koruyan bir döneme doğru götürmektedir. ${ }^{63}$ Küreselleşme ulus-devlet mantığına dayanan, milliyetçilik, emperyalizm ve sömürgecilik uygulamalarını birleştiren dengesiz bir dünya sistemi yaratılmasına neden olmuştur. Bu şekilde bir dünya varlığı/bütünlük içinde var oluş mümkün değildir. Tianxia’nın dünya kurumu felsefesine göre, dünya, dünya bakış açısıyla görülmediği için insanlar tekliğe (oneness) ulaşmada, başka bir deyişe dünya ailesi olmakta yetersiz kalmaktadırlar. ${ }^{64} \mathrm{Bu}$ eksik bakış açısı, devletlerarasında sadece işbirliğini engellemekle kalmayıp 20. yüzyılda Avrupa'nın ve dünyanın deneyimlediği gibi son derece yıkıcı savaşlara neden olabilmektedir. Burada anlatılmak istenen, Zhao Tingyang' in "X'i X'in bakış açısıyla görme" ilkesidir. Dünyada uyum ve barışın sağlanması için, dünyayı ulus gözüyle gören değil, dünya bakış açısıyla gören bir kurum gereklidir.

Ulus-devlet sistemi, Zhao'ya göre küresel düzeydeki birçok problem karşısında yetersiz kalmaktadır. Bu çerçevede Kant'ın dünya federasyonu anlayışından esinlenerek kurulan Birleşmiş Milletler (BM) gibi örgütler de ulus-devlet çerçevesinin dışına çıkamamaktadır. Yani BM, dünya kurumundaki gibi tüm insanların "aileliği” kavramıyla ulusları aşan bir fikir değil, yalnızca uluslararası bir düzenlemedir. ${ }^{65}$ Teoride BM, çoğulcu ve evrensel bir yapıya sahipken, uygulamada her şeyin değil, bazı şeylerin evrenselleşmesini, özellikle Batı modernitesinin evrenselleşmesini sağlamaktadır. Bir süper gücün küreselleşme adına kendi değerlerini evrenselleştirmesinin önüne de geçememektedir. ${ }^{66}$ Öte yandan, tianxia'nın dünya ailesi ve kurumu düşüncesi, tek tek devletlerin çıkarlarının değil, tüm yerküredeki insanların çıkarlarının ön planda tutulduğu, tüm farklılıkların kucaklanarak birliğe ulaşıldığı bir sistem önermektedir.

Tianxia'nın, uygulamaları bakımından insancıl bir otorite olduğu söylenebilir. Yani devlet politik güçle ilgiliyken, tianxia ahlaki otoriteyle ilgilidir. Ahlaki otorite hegemonyadan çok daha üstündür. Bu bağlamda Kant'ın insan ve devlet yaklaşımı da “ahlaki bir buyruğa” dayanması bakımından tianxia felsefesiyle benzerlik göstermektedir. Tianxia'da insancll otoritenin en önemli ilkesi ülkeyi veya toplumu yönetirken insanlar üzerinde baskı kurmak yerine onların kalbini kazanmaktır. ${ }^{67}$ Kant felsefesinde de barışın tesisi için zor kullanmak ya da dışarıdan müdahale etmek yoktur. Halkların kendi istekleriyle toplumsal tabandan doğan bir siyasal değişim meşrudur. Devletlerarasında barışı sağlamayı öngören öncül maddelerden birinde ifade edildiği gibi, hiçbir devlet diğer bir devletin anayasasına veya hükümetine zor kullanarak karışmamalıdır. Ayrıca güç kullanımını sınırlamak adına daimi ordular zamanla ortadan tamamıla kalkmalıdır. Dahası ister küçük ister büyük olsun, hiçbir bağımsız devlet diğer herhangi bir devletin hâkimiyeti altına tevarüs, mübadele, alım-satım veya hibe yollarılla asla girmemelidir. ${ }^{6}$

63 Tingyang, "A PoliticalA Political World Philosophy", s.6.

64 Tingyang, "The Concept of All-under-heaven”, s.8.

65 Zhao Tingyang, "Rethinking Empire from a Chinese Concept 'All-under-Heaven”, Social Identities, Cilt 12, No.1, 2006, s.36.

66 Ibid, s.37.

67 Xuetong, Ancient Chinese Thought, s.44.

68 Kant, Seçilmiş Yazılar, s.264. 
Tianxia'yı imparatorluktan ayıran en önemli özelliklerden biri; imparatorluklar, fetih, egemenlik ve kontrol yolları ile ayakta kalan yönetimleri ifade ederken, tianxia'nın, evrensel değerlere dayanan aydınlanmış bir ülkeyi/krallığı ifade etmesidir. ${ }^{69}$ Tek başına tianxia, medeni dünyadaki davranışlara yön veren üstün bir ahlaki otorite fikrini temsil eden soyut bir kavramdır. Kant'ın "insan" görüşü ve siyaset anlayışı da kozmopolitan bir idealizme, başka bir deyişle ahlak metafiziğine dayanmaktadır. Bu görüşün temelinde kaynağı akılda bulan kesin bir "buyruk” vardır. Kant, matematik ve fizik ilkeleri gibi insan aklında genel-geçer, evrensel ve kesin ilkeler aramıştır. Ona göre hem yasa koyucu hem de yasaya bağlı olan insanlar, sistematik bir birlikle amaçlar krallığını oluşturmaktadırlar.

Kant, "Neyi bilebiliriz?" sorusundan hareket ederek kaynağı akılda bulunan kesin bir "buyruk" ve temel ahlaki ödevi saptamıştır. Bu buyruğa göre, akıl sahibi varlık olan insan, kendisine ve diğer insanlara hiçbir koşulda sadece araç olarak davranmamalı, amaç olarak görüp eylemelidir. Eylemlerinin altında yatan öznel ilkenin aynı zamanda genel bir yasa olmasını isteyebilecekleri şekilde davranmaları gerekmektedir. Daha açı bir deyişle, bir eylemin ahlaksal değeri onunla ulaşılacak amaçta bulunmaz, onu yapmaya karar verdirten istemenin ilkesine bağlıdır. İstemenin ahlaksal olarak iyi olması eylemin ilkesinin herkes için genel bir yasa olmasını isteyebilmekte yatmaktadır. Herkesin diğer insanların haklarını koruduğu demokratik bir dünyada sürekli barışın sağlanması mümkün olacaktır. ${ }^{70}$

Birçok gelişmiş ülkenin yönetim biçimi olarak uyguladığı “demokrasi”, Zhao'ya göre dünya çıkarlarını temsil etmek için uygun değildir. Bunun ilk nedeni, demokrasinin seçimlerde ve anketlerde manipüle edilebilen bireysel arzulara dayanmasıdır. İkinci nedeni ise, iç politikada işleyebilen demokratik kurumların, küresel ölçekte işleyememesidir. ${ }^{71}$ Kitleler çoğunlukla yanlış tercihlerde bulundukları için, Zhao'ya göre insanların iradeleri veya ortak çıkarları, "sosyal eğilimlerin dikkatli bir gözlemiyle” belirlenmelidir. Bu dikkatli gözlemler, Zhao’ya göre, kamu tercihlerinin demokrasiye göre çok daha iyi ve gerçek sonuçlarını belirler. Kitleler, kolaylıkla yanlış yönlendirilebildikleri için, yalnızca elit zümre dünyayı dünya gözüyle görebilir ve insanlar için neyin en iyi olduğuna karar verebilir. Düzen, özgürlükten daha önemlidir ve tianxia, en büyük ve en üst düzen demektir. Çin felsefesinde tianxia'nın meşruluğu mutlaktır ve bu meşruluk, üç temel prensibe bağlanmıştır:

1) Tianxia hükümdarının siyasal meşruluğu bağımsızdır ve herhangi bir ideoloji veya dinden önce gelir;

2) Tianxia’nın hükümdarlığı, evrensel olarak tüm insanların mutluluğunu artırmanın yolunu bilen herkese açıtır;

3) Tianxia hükümdarı, bir diktatör ya da süper güç olmayacak, ancak tianxia’nın yönetimini adil kılacak hakka ve güce sahip olacaktır. ${ }^{72}$

Kant'ın yönetim anlayışı tianxia'daki gibi güçlü bir siyasal erk ya da siyasal elitizm önermemektedir. Aklı ve vicdanı özgür bireylerin temel hak ve özgürlüklerinin garanti altına alındığı liberal bir devlet anlayışı önermektedir. Buna göre ise halklar, insan haklarını sürekli olarak ihlal eden despotik rejimlere karşı kendileri başkaldırmalıdırlar. Kant’a göre ulusal hukuk, uluslararası hukuk ve evrensel hukuk birbirine sıkı sıkıya bağlıdır. Birindeki adaletsizlik diğerlerine de yansıyacaktır. İnsanlık despotizmin tehlikelerine karşı barışçı bir dünya düzeni kurmak için karşılıklı hak ve sorumluluklarla hukukun üstünlügünü koruyacak bir yapı altında birleşmelidir. ${ }^{73}$

69 Gungwu, Renewal: The Chinese State, s.133.

70 Kant, Ahlak Metafiziğinin, s.15.

71 Callahan, “Tianxia, Empire and the World”, s.7.

72 Tingyang, "Rethinking Empire from a Chinese Concept", s.32.

73 Suri, “Conceptualizing China”, s.225-226. 


\section{Kant ve Zhao Felsefesinde "Dünya Barışı"}

Kant'ın sürekli barış için amaçsal maddeleri, tüm devletlerin cumhuriyet rejimi ile yönetilip, dünya vatandaşlık hukukunun bu devletlerin oluşturduğu federasyonca korunduğu bir uluslararası sistemi önermektedir. Vatandaşların kendi kendini yönettiği ve bağımsız yargıyla haklarının korunduğu temsili anayasal sistemler siyasal despotizme karşı liberal sivil toplumu güçlendirmektedirler. Kant’a göre bunun için düşünce, ifade ve iletişim özgürlüğünün korunması şarttır. Benzer şekilde egemen halkların oluşturduğu hukuka dayalı uluslararası sistemde, bir devletin diğer devletler üzerinde gücünü kötüye kullanmasının önüne küresel siyasi yapılanmalarla geçebilecektir. Tüm halkların kendi iradeleriyle dünya vatandaşları olarak oluşturdukları dünya federasyonu barışı sağlayabilecektir.

Öte yandan tianxia'nın eşsizliği, insanlar arasındaki ilişkilere ve problemlere devlet-merkezli olmayan küresel bir bakış açısı getirmesidir. Zhao’nın altını çizdiği gibi bir şeyi en iyi anlamanın yolu ona, onun bakış açısıyla bakmak ve görmektedir. Tianxia, kendi tek ya da değişmez bireysel perspektifimizden değil; insanları, aileyi ve dünyayı onların perspektifinden görmekle daha iyi anlaşılabilmektedir. Batılı sistemlerde en üst siyasi oluşum ulus-devlet kabul edilmekteyken, bu hiyerarşiyi topluluklar ve bireyler izlemektedir. Çin anlayışına göre en üst siyasi oluşum, uluslararası toplum diyebileceğimiz tianxia'dır; devletler bunun alt birimleridir. ${ }^{74}$

Zhao, dünya barışı için Kant'ın öngördüğü bağımsız devletlerden kurulu federasyon fikrine karşı çıkmaktadır. Zhao'ya göre mutlak barış için gereken, tüm devletlerin çıkarlarından bağımsız bir dünya kurumu oluşturulmasıdır. Kant'ın dünya federasyonu görüşü "içeridekiler" ve "dışarıdakiler" yaratacağı için dünyayı bütünleştirmekten ziyade bölücü etki gösterecektir. ${ }^{75}$ Oysa tianxia felsefesinde kimse dışarıda kalmayacak "yabancı" olarak nitelendirilmeyecektir.

Daha önce belirtildiği gibi Kant’a göre barış hem fiili hem de düşünce ve yaklaşım olarak tüm düşmanlıkların sona ermesidir. Benzer biçimde Çince'de ping karakteri (平), Batı'daki barış kavramı ile aynı anlama gelen devletin savaşmaması, savaşın sona ermesi, insanlar veya devletlerarasındaki dostça ilişkiler kurularak korku ve endişenin yok olmasını temsil etmektedir. Fakat bunun yerine Çince'de barış, heh karakteri de eklenerek “uyum içinde barış” anlamına gelen heh-ping (和平) kelimesiyle ifade edilmektedir. Kısacası, barışın temel şartı uyumdur. Dünyanın uyumu dünya barışı için en gerekli koşulken, barış uyumun garantisi değildir. ${ }^{76} \mathrm{Bu}$ nedenle Çinli felsefeciler uyumun önceliği üzerinde durmuşlardır. Savaş ve barış kavramlarının haricinde "uyum" kavramı çatışmaların çözümü için daha makul çözümler sunar ve uzun vadede karşılıklı faydaya ve güvene dayalı ilişkiler geliştirilmesine olanak tanıyarak istikrarlı bir güven ortamı sağlar. Bu durumda "uyum” barıştan daha yüksek bir amaçtır; barış ise yalnızca uyumun bir sonucu olabilir.

Kant düşüncesinde "ebedi barış" tüm devlet yönetimlerinin cumhuriyetçi bir sistemle uyumlaştııılmasına dayanırken, Çin felsefesinde farklı yönetimlerin tianxia (dünya kurumu) altında barışçıl bir uyum içinde var olabilmesiyle mümkündür. Ortak bir tianxia tüm halkların aynı dünyada yaşadığı ve farklılıklara anlayışla yaklaşılması gerektiği anlayışıyla çatışmaları yumuşatıp savaşa sebep olabilecek yanlış anlaşılmaları önleyebilecektir. M.Ö. 500’lü yıllarda yaşamış ünlü bir devlet adamı olan Yanzi'ye göre;

74 Callahan, “Tianxia, Empire and the World", s.9.

75 Yongjin Zhang ve Teng-chi Chang, Constructing a Chinese School of International Relations, Routledge, 2016, s.207.

76 Tingyang, "The Concept of All-under-heaven”, s.12. 
Uyum, iyi hazırlanmış bir çorba gibidir... aynı şey yönetici ve onun bakanı arasındaki ilişki için de geçerlidir... eğer çorba sadece sudan ve biraz daha fazla sudan yapılmış olsaydı, onu yemeye kim tahammül edecekti? Ve müzik, hiç farklılık olmadan çalınsaydı, onu dinlemeye kim tahammül edecekti? Bu yüzden farklılıkların olmadığı, tam bir benzerlik, uyuma uygun değildir. ${ }^{77}$

Tianxia sistemi, bu uyumun nasıl mümkün olduğuna da açıllık getirmektedir. Sistem düşmanı dosta dönüştürme amaciyla huà dí wéi yǒu (化敌为友) kendini ve ötekini dönüştürüp, yani “birçoğu teke” dönüştürerek dünyadaki kaosu düzene sokmayı hedeflemektedir. Bu dönüşüm ise zor kullanarak başka ülkeleri fethetmekten ziyade halkları etkilemekle ve ikna etmekle olmalıdır. ${ }^{78}$

\section{Değerlendirme ve Sonuç}

Bu çalışma temel olarak Uluslararası İlişkiler düşüncesinde Batı-merkezli yaklaşımların hegemonyasına karşı Batılı ve Batılı olmayan yaklaşımların bir arada daha kapsamlı bir dünya görüşü sağlayabileceğini iddia etmektedir. Bunun için çıkış noktası olarak, Batı-merkezli uluslararası ilişkiler paradigmalarının Çin paradigmalarıyla uzlaşmazlığını iddia eden yaygın hipotezlere karşı, Çin ve Batı geleneğinden iki kozmopolitan görüşe odaklanarak bu görüşlerin "dünya barış" kavramlarını araştırmaktadır. Bu amaçla çalışma, Batı literatüründe demokratik barış ve liberal enternasyonalizm gibi yaklaşımlara kaynaklık eden Immanuel Kant'ın “ebedi barış görüşü” ile Çinli felsefeci Zhao Tingyang’ in yorumladığı eski Çin felsefesi tianxia'yı karşılaştırmaktadır. Bu araştırma çerçevesinde biri pratik diğeri teorik olmak üzere iki önemli sonuca ulaşılmıştır.

Birincisi, tianxia'nın çağdaş Çin dış politikasındaki "barış" söyleminde etkisi görülen bir düşünce olması bakımından, çalışma güncel uluslararası gelişmelerde Çin politikalarının ardında yatan normatif yapının daha iyi anlaşılmasına katkıda bulunmaktadır. Nitekim 21. yüzyıldaki jeopolitik gelişmelerle birlikte Çin’in yükselişi göz önüne alındığında, ancak Çin’in uluslararası işbirliği ve barışa ilişkin bakışı dikkate alınarak kalıcı bir dünya barışının sürdürülebilirliği sağlanabilecektir. Bu bağlamda çalışmada Batı́nın Çin’i sürekli bir tehdit olarak görüp ötekileştirerek güvenlikleştirici politikalara itmesi yerine Kantçı liberalizm ve reformist Konfüçyüsçülükle tanımlanan pasifist ve savunmacı Çin kimliğini teşvik etmesi önerilmektedir.

İkincisi, bu çalışma teorik olarak Uluslararası İlişkiler düşüncesinde Huntington gibi etkili isimlerle kabulü artan kültürel görecelilik yaklaşımına karşı Batılı ve Batılı olmayan yaklaşımların uzlaştırılabilir olduğunu göstermektedir. Farklı toplumların farklı siyasal ve sosyal deneyimlerinin farklı modernite anlayışları ve biçimleri geliştirmesi gibi tek tip bir demokrasi ya da barış anlayışı yerine ortak normatif ilkeler üzerinde uzlaşabilen çoklu anlayışların bir arada ele alınabileceğini ve dünyadaki gelişmelere daha kapsamlı açıllamalar getirilebileceğini ortaya koymuştur.

Yapılan kavramsal karşılaştırma şu şekilde özetlenebilir. Kant felsefesinde "dünya barış»", cumhuriyetçi yönetimlerin işbirliğiyle oluşturulmaktadır. Bireyler ve devletlerin her biri özgür, eşit ve bağımsızdır. Ebedi barış ancak, özgürlük, eşitlik ve bağımsızlık ilkeleriyle yönetilen demokrasiler arasında, karşılıklı bağımlılık ilişkisi içinde, dünya vatandaşlığı ve evrensel komşuluk koşullarıyla sınırlandırılan bir federasyonla mümkündür. Bu sistem demokrasiyle yönetilmeyen halkları dışarıda bırakan bir sistemdir. Çin felsefesi tianxia'da ise dünya barışı ve uyumunu sağlayan üç ilke sayılabilir:

77 Zhao Tingyang, "A Political World Philosophy”, s.14.

78 William A. Callahan, "Chinese Visions of World Order: Post-hegemonic or a New Hegemony?", International Studies Review, Cilt 10, 2008, s.752. 
Farklı olanı dışarıda bırakmayan, kendi/öteki ilişkisi sağlayan “her şeyi kucaklama” (无外, wú wài); “dünyanın hep birlikteliği” anlamına gelen tóng yĩ xing (同一性); kendini ve ötekini dönüştürüp “tekliğe” ulaşmayı sağlayan "düşmanı dosta dönüştürme” huà dí wéi yǒu (化敌为友). Bu ilkelerle insanların tek bir aile olarak algılandığı bir dünya kurumu, başka bir deyişle tianxia'nın kurulması mümkün olacaktır.

Kant felsefesinde insanlar tek bir aile olarak düşünülmese de dünya insanların ortak mirası olduğu için evrensel komşuluk ilkesiyle tianxia'daki gibi "herkes kucaklanıp" hiçbir yabancı başka devletin topraklarından dışlanmamaktadır. Tianxia'da tüm bireyler, uluslararası toplum çatısı altında bir aile olarak kabul edilmektedir. Kant felsefesinde de insanlığın ortak yararına geliştirilen bilimsel, sanatsal ve ekonomik faaliyetlerle devletlerarasında dostça ilişkiler kurulabilir. Tianxia'daki "dünyanın hep birlikteliği”, Kantçı paradigmada dünya federasyonuyla mümkündür.

Tianxia, Kant felsefesinden farklı olarak devlet-merkezli bir dünya barışı öngörmez. Zhao Tingyang’a göre devlet, siyasal güçle ilgiliyken, tianxia'nın temelindeki dünya kurumu düşüncesi devletlerin ve ulusların üstünde ahlaki bir otoriteye dayanmaktadır. Bu insancıl otorite meşruiyetini tüm ideoloji ve dinlerden önce gelen uyum, adalet ve mutluluk sağlayarak insanların kalbini kazanan bir birlik anlayışıyla oluşturmaktadır. Cumhuriyetçi Kant felsefesinde ise devletler meşruiyetini halklarına eşitlik, özgürlük ve bağımsızlık sağlamalarından almaktadır. İktidar halkın egemenliğini temsil edip korumaktadır. İki sistem de güç ve zor kullanımına yer vermeyip farklı unsurlarla insanların rızasını kazanmaya önem vermektedir.

Kant felsefesinde "aydınlanma" kavramı kişinin kendi aklını bir ergin olmayış durumundan kurtarıp bir kılavuz olmaksızın kullanması anlamına gelmektedir. Halklar da hükümdarlardan bağımsız kendi kaderlerini kendi eşit ve özgür iradeleriyle tayin etmelidirler. Öte yandan Zhao'ya göre uyum, adalet ve mutluluk sağlayan düzen özgürlükten daha önemlidir. Bunun için halkın yanlış yönlendirmelere karşı sosyal eğilimlerinin araştırılması ve dünyayı tianxia gözüyle gören seçkin bir sınıf̧ça düzenin sağlanması gerekmektedir. Bu seçkinci görüş, Kant felsefesiyle farklılık göstermektedir.

Kant felsefesindeki özgürlük, eşitlik ve bağımsızlık ilkelerinin uluslararası düzeyde kabul görmesi cumhuriyetçi yönetimler arasında "demokratik barışı” sağlamaktadır. Öte yandan bu yaklaşım demokrasi ile yönetilen ve demokrasiyle yönetilmeyen devletler arasında sürekli bir güç mücadelesi ve savaşa neden olabilecektir. Tianxia ise farklılıkların olmadığı bir dünya hayal edilemeyeceğinden, uyumla farklılıkları muhafaza etmenin tüm insanlığın yararına en iyi işbirliğini yaratacağını öngörmektedir. Böylelikle insanlar kendi "rıza"larıyla uyum sayesinde "düşmanı dosta dönüştürme" ilkesini gerçekleştirecektir.

Özetle, dünya politikalarında farklı kimlikleri, düşünceleri ve yönetimleri “tehdit” olarak algılayan yaklaşımlar yerine Çin felsefesi tianxia'nın uyum, adalet ve mutluluğu sağlayan dünya kurumu anlayışındaki "dünyanın hep birlikteliği", "düşmanı dosta dönüştürme" ve "her şeyi kucaklama" ilkeleriyle ve Kant'ın eşitlik, özgürlük ve bağımsızlık ilkelerinin bir arada hedeflendiği küresel düzeyde bir barış için daha kapsamlı diplomatik ve stratejik yolun sürdürülmesi mümkün görünmektedir. 


\section{Kaynakça}

Acharya, Amitav ve Barry Buzan. "Why is there no non-Western international relations theory? An introduction”, Amitav Acharya ve Barry Buzan (der.), Non-Western International Relations Theory: Perspectives On and Beyond Asia, Routledge, 2010, s.1-26.

Barash, David P. Approaches to Peace: A Reader in Peace Studies, NY, Oxford University Press, 2013.

Behera, Navnita Chadha. "Reimagining IR in India", Amitav Acharya ve Barry Buzan (der.), Non Western International Relations Theory: Perspectives On and Beyond Asia, Routledge, 2010, s.92-117.

Bernstein, Richard ve Ross Munro. The Coming Conflict with China, NY, Vintage Books, 1997.

Bilgin, Pinar. “The 'Western-Centrism'of Security Studies: Blind Spot or Constitutive Practice?”, Security Dialogue, 2010, Cilt 41, No.6, s.615-622.

Bilgin, Pınar. “Thinking Past 'Western'IR?”, Third World Quarterly, Cilt 29, No.1, 2008, s.5-23.

Callahan, William A. “Chinese Visions of World Order: Post-hegemonic or a New Hegemony?”, International Studies Review, Cilt 10, 2008, s.749-761.

Callahan, William A. "Tianxia, Empire and the World: Soft Power and China's Foreign Policy Discourse in the 21st Century”, BICC Working Paper Series, British Inter-University China Centre, No.1, 2007.

Caranti, Luigi. "Perpetual War for Perpetual Peace? Reflections on the Realist Critique of Kant's Project", Journal of Human Rights, Cilt 5, No.3, 2006, s.341-353.

Carlson, Allen. "Moving Beyond Sovereignty? A Brief Consideration of Recent Changes in China's Approach to International Order and the Emergence of the Tianxia Concept", Journal of Contemporary China, Cilt 20, No.68, 2011, s.89-102.

Cheng, Joseph Y. S. "Convincing the World of China's Tradition to Pursue Universal Harmony", Journal of Chinese Political Science, Cilt 17, No.2, 2012, s.165-185.

Ching, Julia. "Chinese Ethics and Kant", Philosophy East and West, Cilt 28, No.2, Sinological Torque (Apr. 1978), s.161-172.

Davis, Michael C. "Constitutionalism and Political Culture: The Debate over Human Rights and Asian Values", 11 Harvard Human Rights Journal, 109, 1998, s.109-147.

Eisenstadt, S. N. “Multiple Modernities”, Daedalus, Cilt 129, No.1, December 2000, s.1-29.

Engle, Karen. "Culture And Human Rights: The Asian Values Debate In Context”, 32 N.Y.U. J. International Law. \& Politics.291, 2000, s.291-333.

Friedman, Edward. "Immanuel Kant's Relevance to an Enduring Asia-Pacific Peace", Edward Friedman ve Barrett L. McCormick (der.), What if China Doesn't Democratize? Implications for War and Peace, NY, M. E. Sharpe, 2000, s.224-252.

Geeraerts, Gustaaf ve Men Jing. "International Relations Theory in China”, Global Society, Cilt 15, No.3, 2001, s.251-276.

Gleditsch, Nils Petter, Jonas Nordkavelle ve Håvard Strand. “Peace Research—Just the Study of War?” Journal of Peace Research, No.51, March 2014, s.145-158.

Goertz, Gary, Paul F. Diehl ve Alexandru Balas. The Puzzle of Peace: The Evolution of Peace in the International System, NY, Oxford University Press, 2016.

Guoli, Liu. "Domestic Sources of China's Emerging Grand Strategy", Journal of Asian and African Studies, Cilt 43, No.5, 2008, s.543-561.

Hasgüler, Mehmet ve M. Bülent Uludağ. Uluslararası Örgütler, Ankara, Nobel Yayınevi, 2005.

Hui, Victoria Tin-bor. "Toward a Confucian Multicultural Approach to a Liberal World Order: Insights from Historical East Asia”, 99 American Society of International Law, Cilt 99, 2005, s.413-416.

Huntington, Samuel P. The Clash of Civilizations and the Remaking of World Order, NY, Simon\&Schuster, 2011.

Ikenberry, John. "The Rise of China and the Future of the West: Can the Liberal System Survive?", International Affairs, Cilt 87, No.1, 2008, s.23-37

Johnston, Alastair Iain. "What (If Anything) Does East Asia Tell Us About International Relations Theory?", Annual Review of Political Science, Cilt 15, s.53-78.

Kant, Immanuel. Seçilmiş Yazilar, İstanbul, Remzi Kitabevi, 1984.

Kant, Immanuel. “Aydınlanma Nedir Sorusuna Yanıt (1784)”, Immanuel Kant (der.), Seçilmiş Yazılar, İstanbul, Remzi Kitabevi, 1984, s.211-221. 
Kant, Immanuel. “Sürekli (Ebedi) Barış Üstüne Felsefi Bir Deneme (1795)”, Immanuel Kant (der.), Seçilmiş Yazilar, İstanbul, Remzi Kitabevi, 1984, s.224-266.

Kant, Immanuel. Ahlak Metafiziğinin Temellendirilmesi, Ankara, Türkiye Felsefe Kurumu, 2002.

Kleingeld, Pauline. “Approaching Perpetual Peace: Kant's Defence of a League of States and his Ideal of a World Federation”, European Journal of Philosophy, Cilt 12, No.3, 2004, s.304-325.

Lucht, Marc. “Toward Lasting Peace: Kant on Law, Public Reason, and Culture”, American Journal of Economics and Sociology, Cilt 68, No.1, 2009, s.303-326.

Noesselt, Nele. “Is There a Chinese School of IR?”, GIGA Working Papers, No.188, 2012.

Qin, Yaqing. "Why There is no Chinese International Relations Theory", International Relations of the AsiaPacific, Cilt 7, 2007, s.313-340.

Reihman, Gregory M. “Categorically Denied: Kant’s Criticism of Chinese Philosophy”, Journal of Chinese Philosophy, Cilt 33, No.1, 2006, s.51-65.

Ross, Robert. "Balance of Power Politics and the Rise of China: Accommodation and Balancing in East Asia", Security Studies, Cilt 15, No.3, 2006, s.355-395

Shambaugh, David. “International Relations Studies in China: History, Trends and Prospects”, International Relations of the Asia-Pacific, Cilt 11, No.3, 2011, s.339-372.

Shani, Giorgio. “Towards a Post-Western IR: The Umma, Khalsa Panth, and Critical International Relations Theory”, International Studies Review, Cilt 10, No.4, 2008, s.722-734.

Smith, Karen. "Has Africa Got Anything to Say? African Contributions to the Theoretical Development of International Relations”, The Round Table, Cilt 98, No.402, 2009, s.269-284.

Suri, Manik V. “Conceptualizing China Within the Kantian Peace”, Harvard International Law Journal, Cilt 54, No.1, Winter 2013, s.219-232.

Tong, Shijun. “Chinese Thought and Diological Universalism”, Gerard Delanty (der.), Europe and Asia Beyond East and West, Routledge, 2006, s.305-316.

Wang, Fei-Ling. "Between Tianxia and Westphalia: Chinese Searches its Position in the World”, Paper Presented at the Annual Meeting of the American Political Science Association, Seatle, 2011.

Wang, Gungwu. Renewal: The Chinese State and the New Global History, The Chinese University Press, 2013.

Webel, Charles ve Johan Galtung (der.). Handbook of Peace and Conflict Studies, NY, Routledge, 2009.

Yan, Xuetong.Ancient Chinese Thought, Modern Chinese Power,Princeton University Press, 2011.

Yurdusev, Nuri. "Uluslararası İlişkiler Öncesi”, Atila Eralp(der.), Devlet, Sistem ve Kimlik: Uluslararası İlişkilerde Temel Yaklaşımlar, İletişim Yayınları, 1996, s. 47-51.

Zhang, Yongjin. “China's Entry into International Society: Beyond the Standart of 'Civilisation”, Review of International Studies, Cilt 17, No.1, 1991, s.3-16.

Zhang, Yongjin ve Teng-chi Chang.Constructing a Chinese School of International Relations, Routledge, 2016.

Zhao, Tingyang. "All-Under-Heaven and Methodological Relationism: An Old Story and New World Peace", Fred Dallmayr veZhao Tingyang (der.), Contemporary Chinese Political Thought: Debates and Perspectives, The University Press of Kentucy, 2012, s.46-66.

Zhao Tingyang. “Chinese World Outlook: All-under-Heaven System”, Zhenglai Deng (der.) Globalization and Localization: The Chinese Perspective, World Scientific Publishing Company, 2011, s.139-155.

Zhao Tingyang. "Rethinking Empire from a Chinese Concept 'All-under-Heaven”, Social IdentitiesCilt12, No.1, 2006, s.29-41.

Zhao, Tingyang. The Tianxia System: An Introduction to the Philosophy of a World Institution, China Renmin University Press, 2011.

Zhao, Tingyang. “The Concept of All-under-heaven: A Semantic and Historical Introduction”, http://www. doc88.com/p-998593945884.html (Erişim Tarihi15 Eylül 2015).

Zhao, Tingyang. "A Political World Philosophy in terms of All-Under-Heaven (Tian-xia)”, Diogenes, Cilt 56, No.5, 2009, s.5-18.

Zheng, Feng. "Debating the Chinese Theory of International Relations”, Fred Dallmayr ve Zhao Tingyang (der), Contemporary Chinese Political Thought: Debates and Perspectives, The University Press of Kentucy, 2012, s.67-87.

Zhou, Lain. "The Most Fashionable and the Most Relevant: A Review of Contemporary Chinese Political Philosophy”, Diogenes, Cilt 56, No.1, 2009, s.128-137. 